\title{
Deoxyribonucleic Acid (DNA) and Antibodies to DNA in the Serum of Patients with Systemic Lupus Erythematosus*
}

\author{
E. M. TAN, † P. H. Schur, + R. I. CARr, ANd H. G. Kunkel $\S$ \\ (From the Rockefeller University, New York, N. Y.)
}

Although antibodies to deoxyribonucleic acid (DNA) and to many other cell constituents have been described in patients with systemic lupus erythematosus (SLE), the relationship of these antibodies to tissue injury in the disease has remained obscure (2-6). Some studies have suggested an association of DNA antibodies with the acute stages of the disease $(7,8)$. One of the pathogenic mechanisms that might be involved has been suggested by studies in experimental animals which showed that antigen-antibody complexes produce renal disease and vasculitis (9-12).

Evidence for the in vivo reaction of circulating antibodies with autologous tissues has been provided by the recent observation that in the skin lesions of patients with SLE there is widespread binding of serum antibodies to cell nuclei and nuclear material (13). It has been suggested that in addition to the immunological reactions observed in the skin lesions by the fluorescent antibody technique, certain soluble tissue antigens may be released into the circulation during tissue injury and combine with specific antibody to form immunological complexes resulting in damage to other organs as well. Recent studies showed that DNA is one of a number of soluble antigenic tis-

* Submitted for publication October 18, 1965 ; accepted July 28, 1966.

This investigation was supported in part by U. S. Public Health Service grant FR-00102 from the General Clinical Research Centers Branch of the Division of Research Facilities and Resources and by grant 7 F2 AM-20, 122-02.

A preliminary report of these studies has appeared in abstract form (1).

$\dagger$ This work was done during the tenure of a postdoctoral fellowship from the Arthritis Foundation. Present address: Washington University School of Medicine, St. Louis, Mo.

$\$$ Fellow of the Helen Hay Whitney Foundation.

$\S$ Address requests for reprints to Dr. Henry G. Kunkel, Rockefeller University, New York, N. Y. 10021. sue components that can be readily extracted from organ homogenates in vitro $(14,15)$.

Our studies were undertaken to determine whether soluble tissue antigens can be detected in the circulation in patients with SLE that might react with the known antibodies to produce renal injury. The results showed that DNA is present in the sera of certain patients with SLE, and various studies raised the possibility of its participation with antibody in the formation of immunological complexes in vivo.

\section{Methods}

Collection of sera. Blood was drawn in siliconized syringes and allowed to clot at room temperature. As soon as the clot had formed, the cellular elements were removed by centrifugation. Sodium azide at a final concentration of $0.1 \%$ was added to the serum, which was stored at $4^{\circ} \mathrm{C}$ or frozen at $-20^{\circ} \mathrm{C}$. For the preparation of serum or plasma free from contamination with cellular breakdown products, the method of Gupta and Herriott (16) was used.

Immunologic techniques. Precipitin reactions by double diffusion in agarose (SeaKem) 1 were performed according to the technique previously described (15). Quantitative microcomplement fixation was by the method of Wasserman and Levine (17). In some instances this procedure was used to determine the concentration of DNA as well as the relative concentration of antibody to DNA. In most experiments a more gross determination of DNA and relative antibody concentration was made employing the gel diffusion technique. This was employed for the results in Table I and Figures 4 and 5 with the complement fixation procedure utilized as a check for some of the determinations. For antigen analysis the DNA in an unknown serum was compared directly with known amounts of DNA added to normal serum with regard to the position of the precipitin line. One standard antibody-containing serum was utilized for all such analyses. For relative antibody concentrations this standard antiserum and dilutions of this antiserum were compared with unknown sera according to the position of the precipitin line for various known concentrations of DNA.

1 Bausch and Lomb, Rochester, N. Y. 
Preparation and treatment of DNA. Three different sources of DNA, calf thymus, ${ }^{2}$ salmon sperm, ${ }^{2}$ and Escherichia coli, ${ }^{3}$ were used in the initial studies, but since no significant differences were found in the results obtained, the majority of the experiments were performed with calf thymus DNA. Highly polymerized calf thymus DNA was dissolved in phosphate $(0.01 \mathrm{M})$ buffered saline ( $\mathrm{pH} \mathrm{7.0)}$ at a concentration of $1 \mathrm{mg}$ per $\mathrm{ml}$ as the stock solution. Thermal denaturation was carried out by heating solutions of $0.5 \mathrm{mg}$ per $\mathrm{ml}$ for $10 \mathrm{~min}$ utes in a boiling water bath and immediately cooling in an ice bath. Sonically disrupted DNA was prepared by treating solutions of native DNA, $0.2 \mathrm{mg}$ per $\mathrm{ml}$, with a Branson sonifier at maximal output for 2 minutes in an ice bath. For precipitin reactions, native DNA was employed at a concentration of $1 \mathrm{mg}$ per $\mathrm{ml}$, thermally denatured DNA at $0.5 \mathrm{mg}$ per $\mathrm{ml}$, and sonically disrupted $\mathrm{DNA}$ at $0.2 \mathrm{mg}$ per $\mathrm{ml}$.

Chemical determination of DNA in serum. A modification of the method of Giles and Myers (18) was used for the chemical determination of DNA in human strum (19). To $1 \mathrm{ml}$ of test serum an equal volume of $20 \%$ perchloric acid was added and the resulting mixture heated at $70^{\circ} \mathrm{C}$ for 15 minutes. This was then centrifuged twice at $2,000 \mathrm{rpm}$ for 45 minutes, and the resulting clear supernatant was used for the diphenylamine reaction. In experiments to determine the reliability of this method for determining DNA in serum, studies were carried out in parallel with DNA in saline and DNA added to normal serum. In the region between $5 \mu \mathrm{g}$ and $20 \mu \mathrm{g}$ DNA per $\mathrm{ml}$ in saline or the same concentrations of DNA added to normal serum, there was no difference in the color reaction with diphenylamine reagent. The method was not sensitive enough to detect concentrations of DNA below $5 \mu \mathrm{g}$ per $\mathrm{ml}$. Where the concentration in serum was above $20 \mu \mathrm{g}$ DNA per $\mathrm{ml}$, suitable dilutions were made to bring the concentration to between 5 and $20 \mu \mathrm{g}$ per $\mathrm{ml}$.

\section{Results}

Precipitating antibodies to $D N A$. Sera from patients with SLE that contained antibodies to DNA provided a method for the detection of DNA in serum. Employing double diffusion in agar, we demonstrated the extreme sensitivity and specificity of the method. Figure 1 illustrates the reaction of two different SLE sera with native DNA (N-DNA), sonically disrupted DNA (S-DNA), and heat-denatured DNA (H-DNA). One of these sera detected an antigenic determinant or determinants possessed in common by the three different preparations of DNA as shown by the line of identity in the upper set of wells, whereas the

2 Worthington Biochemicals, Freehold, N. J.

${ }^{3}$ Gift of Dr. M. Jesaitis, Rockefeller University, New York, N. Y.

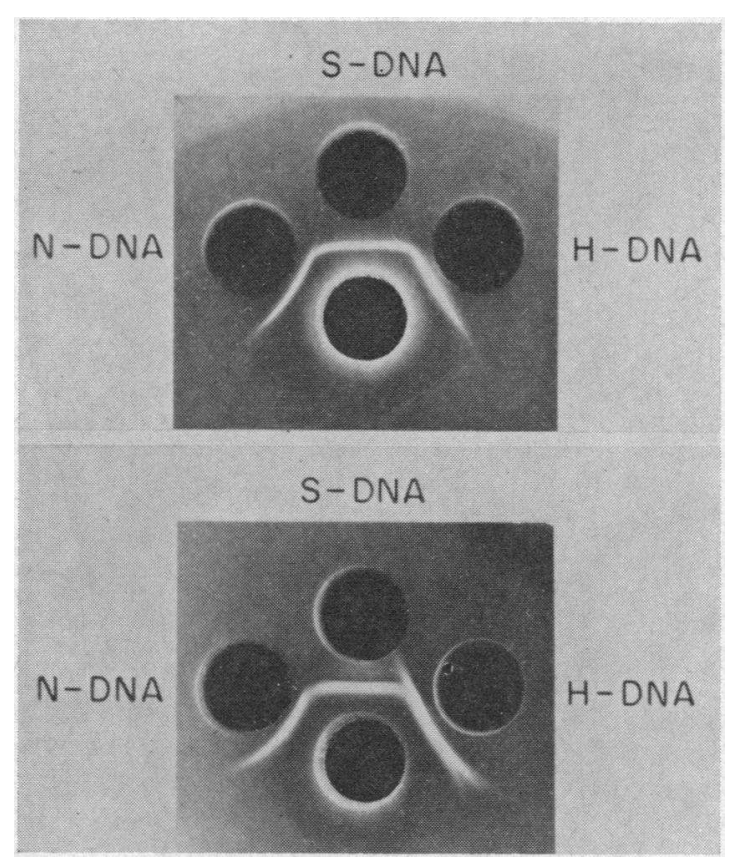

Fig. 1. Reaction of two different SyStemic LUPUS ERYTHEMATOSUS (SLE) SERA WITH DIFFERENT PREPARATIONS OF DNA, NATIVE (N-DNA), SONICALly DisRUPted (S-DNA), and heat-denatured (H-DNA). Serum in upper group of wells gave identical precipitin line with the different preparations of DNA. Serum in lower group of wells gave a line with $\mathrm{H}$-DNA that spurred over sonically disrupted and native DNA.

serum in the lower set of wells showed a broad precipitin line with denatured DNA part of which spurred over sonically disrupted and native DNA. The reaction of sera with native DNA usually produced a precipitin line curved towards the antigen well, a phenomenon consistent with the high molecular weight of native calf thymus DNA. Sonically disrupted DNA appeared to consist of smaller fragments antigenically identical to native DNA. This is illustrated in Figure 1, where the lower molecular weight S-DNA preparation diffused farther away from the antigen well and formed straight precipitin lines with antibody. The precipitin lines usually showed complete identity with native DNA. Heat-denatured DNA reacted with certain SLE sera, as typified by the serum in the lower set of wells, to give a precipitin line that spurred over sonically disrupted or native DNA. A third type of pattern was also observed in rare instances where native DNA spurred over the heat-denatured DNA. The commonest pattern observed, however, was one showing slight spur- 


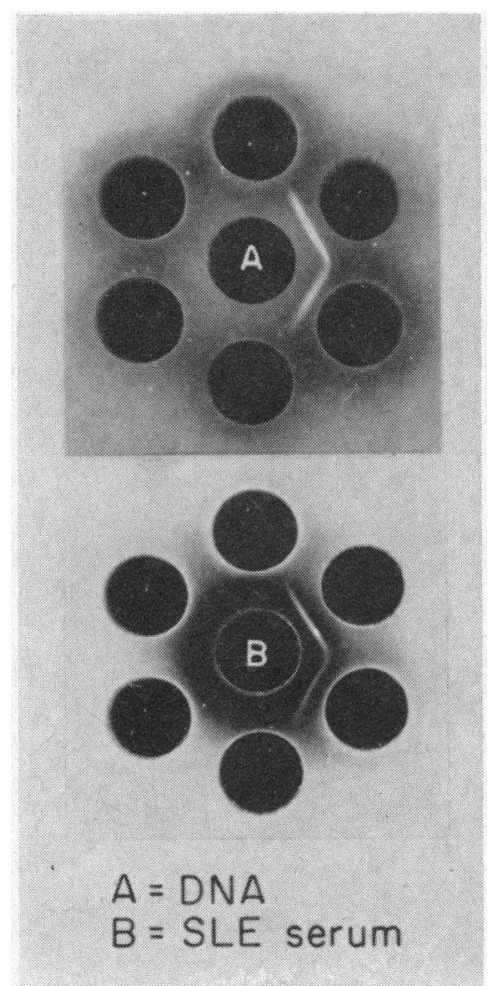

Fig. 2. REaction of PERIPHERAL Wells filled With SIX SLE SERA With CENTRAL well A CONTAINiNg CALF THYMUS DNA. Two of the sera that had precipitating antibodies to DNA also reacted in an identical fashion with SLE serum in well $B$, indicating the presence of DNA in serum B.

ring of heat-denatured DNA over native DNA. In such SLE sera it was shown by quantitative microcomplement fixation that serum absorbed with native DNA retained its ability to fix complement with denatured DNA. These results are in line with previous studies on SLE sera (20) and in experimental animals (21-24) where singlestranded DNA showed the major reactivity in complement fixation tests. The spurs observed in the present study, however, were not noted in previous studies utilizing precipitin reactions.

Demonstration of DNA in serum. The ability to select sera with precipitating DNA antibodies provided a sensitive and reliable method for the detection of DNA in other sera. This is demonstrated in Figure 2. Six SLE sera were set up in peripheral wells against central well A containing a solution of DNA, and two of these sera had precipitating DNA antibodies. When these sera were reacted against another SLE serum in well
$\mathrm{B}$, the same two sera reacted to give precipitin lines, suggesting that DNA was present in the SLE serum in B. This was substantiated by the experiments illustrated in Figure 3. A SLE serum St previously demonstrated to contain precipitating DNA antibody reacted with another serum $\mathrm{Va}$ to give a precipitin line of identity with the DNA line. When serum St was absorbed with DNA, the reaction with both $\mathrm{Va}$ and DNA was abolished. Further evidence that the reacting component in serum Va was DNA was demonstrated by the removal of reactivity when deoxyribonuclease was added to the serum, whereas ribonuclease and trypsin digestions had no effect.

The sensitivity of the method for detecting DNA in serum was determined by adding native DNA to normal sera known to be free of this material. It could be shown that added DNA in amounts of $1 \mu \mathrm{g}$ per $\mathrm{ml}$ of serum could be detected by selecting sera containing antibody and that a gross quantitation could be obtained for unknown sera by direct comparison of the position of the lines with standard solutions of DNA.

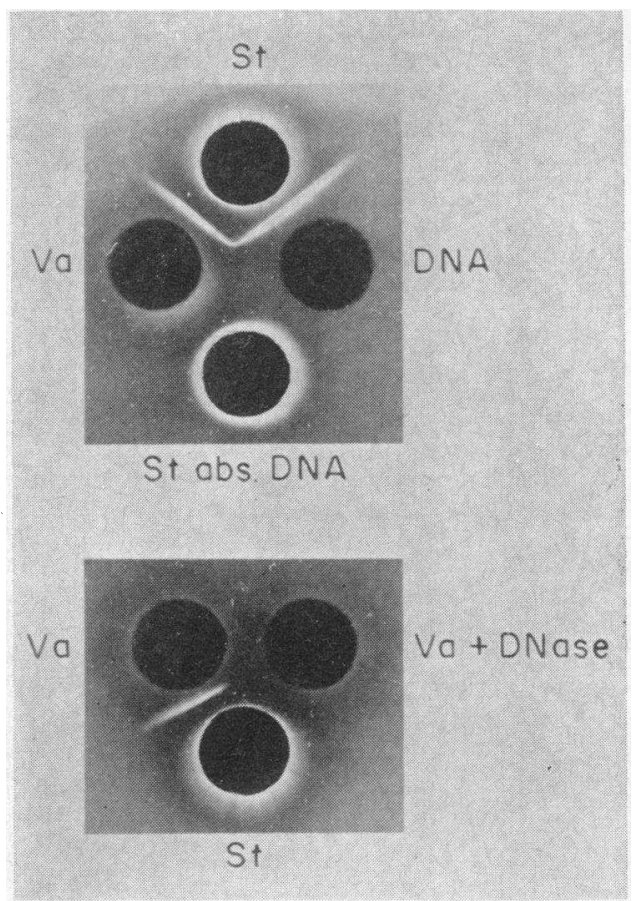

Fig. 3. REACtion of SERUM St, CONTAINING PRECIPItating antibody to DNA, with SLE SERUM VA to give LINE OF IDENTITY WITH DNA. Reaction was abolished by absorbing St with DNA and by digestion of serum Va with deoxyribonuclease. 
TABLE I

Comparison of immunologic and chemical determinations of DNA in serum

\begin{tabular}{ccc}
\hline \hline $\begin{array}{c}\text { Systemic lupus } \\
\text { erythematosus } \\
\text { serum }\end{array}$ & $\begin{array}{c}\text { Precipitin } \\
\text { analysis }\end{array}$ & $\begin{array}{c}\text { Diphenylamine } \\
\text { reaction }\end{array}$ \\
& ++++ & $\mu g / m l$ \\
$\mathrm{Va}$ & ++ & 60 \\
$\mathrm{Sa}$ & ++ & 18 \\
$\mathrm{Th}$ & + & 16 \\
$\mathrm{Jo}$ & 0 & 5 \\
$\mathrm{Ci}$ & 0 \\
\hline
\end{tabular}

Efforts were made to demonstrate whether DNA in serum could be determined by chemical methods and whether the values correlated with the strength of the precipitin reactions. The results of such an experiment are presented in $\mathrm{Ta}$ ble I, which shows the general correspondence of results obtained by immunological and chemical methods.

Since peripheral blood contains cellular components, it was important to determine whether DNA in serum could in part represent an artifact arising out of breakdown of leukocytes after venipuncture. We found that in patients with DNA in serum collected from clotted whole blood, the cell-free plasma and serum from cell-free plasma contained similar amounts of DNA. Normal sera that we collected using the minimal precautions to prevent hemolysis and cellular breakdown as outlined under Methods were never found to contain DNA by antigenic analysis. In fact, it was difficult to cause DNA to appear by repeated freezing and thawing of whole blood or by permitting it to stand at room temperature for prolonged periods. However, normal sera obtained from outside sources where variable and crude procedures were used sometimes contained DNA. This correlated to some degree with the hemolysis present. The exact cause of the appearance of this DNA was not entirely clear, but we obtained some evidence that it was related in part to prolonged periods of standing before removal of the serum from the cells. Such sera, which we did not take, were excluded from the study.

Addition of DNA to normal serum followed by incubation at $37^{\circ} \mathrm{C}$ had only a slight effect on the intensity of the precipitin line with DNA antibody, and in some cases, no visible effect. The nucleases in serum did not represent a major concern for the detection of DNA provided minimal precautions were taken in the collection of the serum and prolonged periods at room temperature avoided.

Characterizations of serum DNA. The fact that the DNA antibodies in some SLE sera distinguished native from denatured DNA made it possible to determine which type resembled that found in serum. It was clear that a reaction of identity. with native DNA occurred in all instances studied, and that serum DNA was spurred over by heat-denatured DNA when the appropriate antisera were utilized.

Density gradient analysis indicated that the DNA was of moderately high molecular weight and was not markedly degraded. It sedimented with, and slightly above, the $19 \mathrm{~S}$ globulin marker in normal serum. We obtained some evidence that the molecular weight was variable in different sera. Electrophoretic analysis demonstrated that the serum DNA was typically acidic and closely resembled the standard material.

Occurrence of $D N A$ in serum in SLE. DNA was found in the sera of 11 of 95 patients with SLE that were studied. In five instances it was observed in multiple serum specimens from the same patient. Figures 4 and 5 illustrate serial studies in two of these patients. In the first pa-

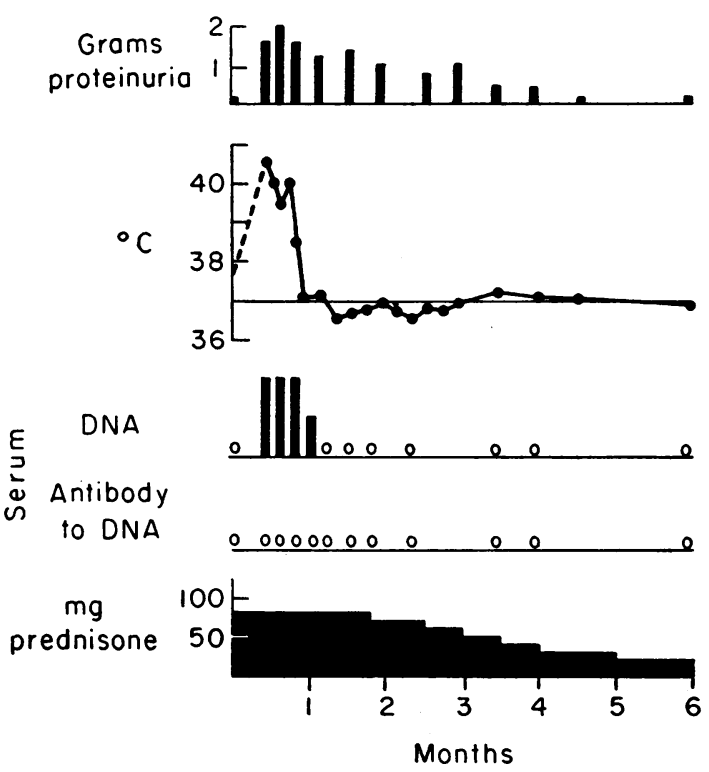

Fig. 4. Presence of DNA in consecutive SERUM SAMPLES OF A PATIENT WITH SLE DURING ACUTE PHASE OF ILLNESS ACCOMPANIED BY HIGH FEVER AND ONSET OF PROTEINURIA. 

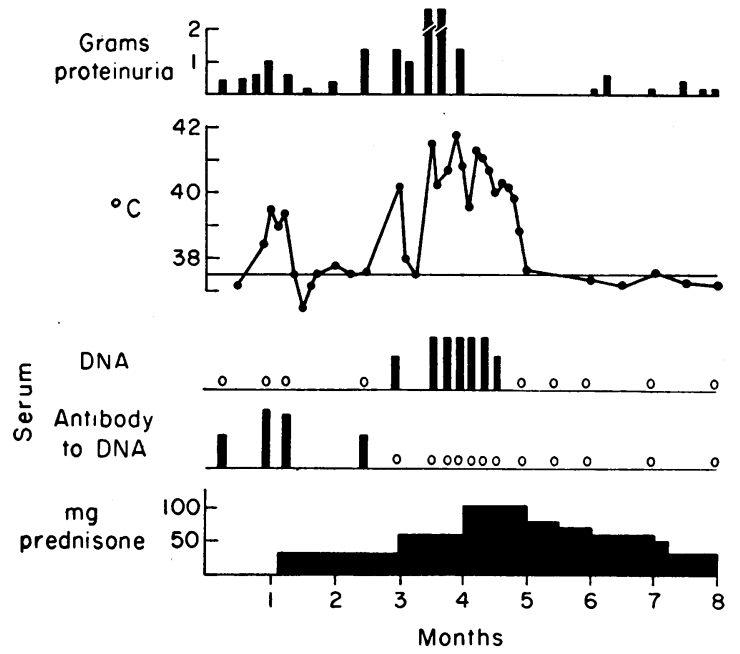

Fig. 5. Course of a patient with SLE initially SHOWING DNA ANTIBODY IN FOUR CONSECUTIVE SERUM SAMPLES. Exacerbation of illness with very high fever and increased proteinuria coincided with appearance of DNA in serum and disappearance of antibody. DNA was not detected after acute illness had subsided. Scales are similar to Figure 4.

tient (Figure 4) DNA appeared in the serum during an exacerbation of the disease and then was noted in four consecutive bleedings during hospitalization. One bleeding in the outpatient clinic before the exacerbation failed to show DNA in the serum although the LE cell test was positive and antinuclear antibodies were demonstrated by the fluorescent antibody technique. Antibodies to DNA, however, were not detected. With improvement the DNA in the serum disappeared and was not observed again.

The second patient (Figure 5) showed antibody to DNA in the serum over a period of several months. During an exacerbation of the disease characterized clinically by generalized skin rash, high fever, and increased proteinuria, DNA appeared in the serum. This was detected in seven consecutive serum samples but disappeared with clinical improvement. Subsequent studies over a 2-year period of remission have failed to show either DNA or DNA antibody. It was possible in this patient to demonstrate that earlier sera with DNA antibody gave precipitin reactions with later sera containing DNA (Figure 6). The serum of March 26 contained little of either DNA or antibody to DNA and might be considered a transition specimen from the stage of DNA antibody to the stage of circulating DNA. Since this transition occurred over a relatively short period of time, the possibility is raised that complexes of DNA and antibody may have formed.

Additional information concerning the possible formation of antigen-antibody complexes consisting of DNA and anti-DNA antibodies was obtained from studies of another patient. In this case the initial specimen of serum showed the presence of native DNA together with antibodies to denatured DNA. A second serum taken 4 days later and all subsequent sera showed no DNA but antibodies to both native and denatured DNA. Only at the time when native DNA was present did this individual's serum lack antibodies to native DNA.

Many investigators have established the important role of complement binding in tissue injury

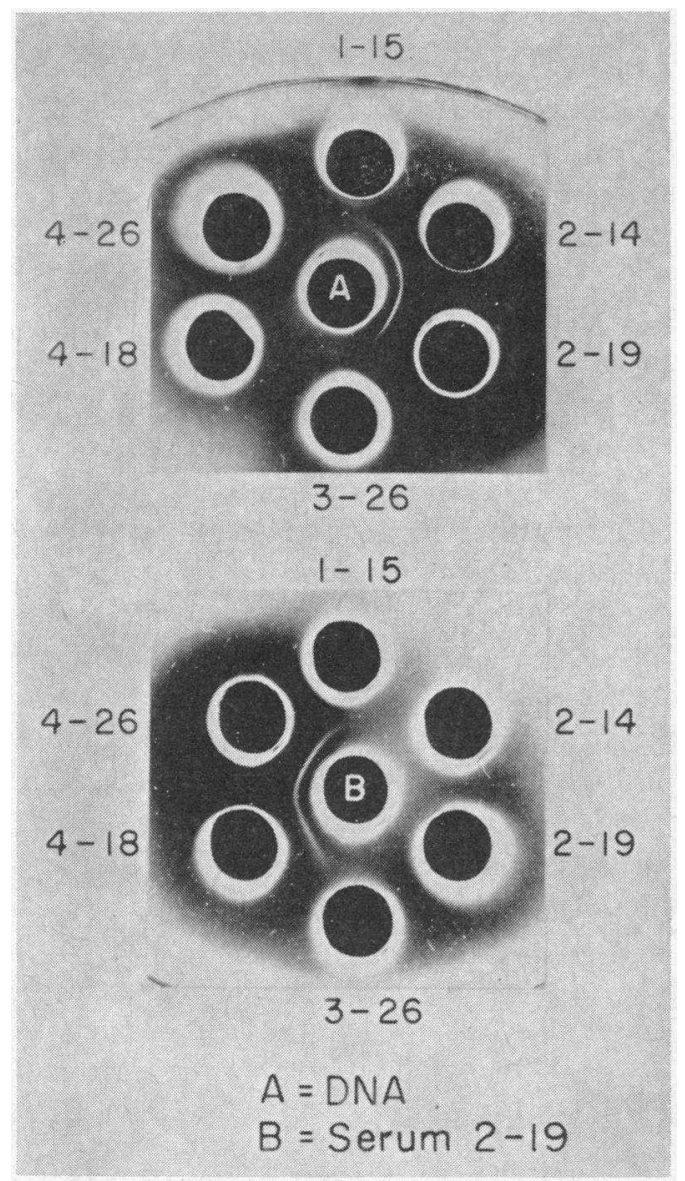

Fig. 6. Serological STUdies ON SERA From Patient iLlustrated IN Figure 5 SHOWINg EARLy SERUM (FEBRUARY 19) WITH DNA ANTIBODY REACTING WITH LATER SERA (APRIL 18 AND April 26) containing DNA. 
produced by immunological complexes, and it was of interest to determine whether sera with DNA antibody would fix complement with sera containing DNA. This is illustrated in Figure 7, where a serum containing antibody was shown to fix complement with calf thymus DNA and with SLE serum Va shown by precipitin studies to contain DNA.

The exact incidence of the appearance of DNA in SLE is not apparent from this study. In all cases where it was observed it was a transitory phenomenon, and its detection was in considerable part determined by the number of specimens taken particularly during acute exacerbations. In nine of the eleven cases where DNA was found it appeared during acute febrile periods. In four of the cases it was found at a time when a skin rash was present. The presence of DNA antibodies during the acute stages of the disease in certain of the patients also complicates the picture. In such instances small amounts of DNA would not be detected.

Presence of DNA in other disease states. The immunologic precipitin technique was employed to determine whether DNA was present in sera from other disease states (Table II). It was not present in measurable amounts in 30 normal sera examined nor in most pathological sera. Ten sera

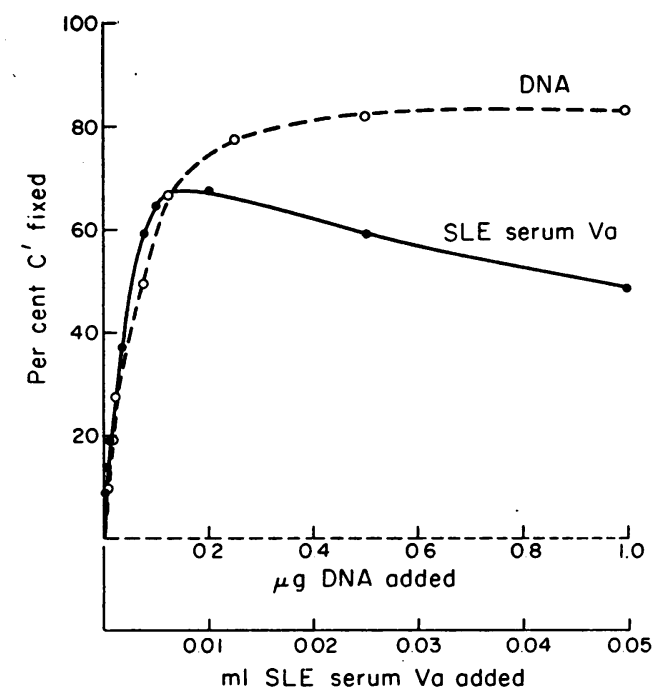

Fig. 7. Reaction of SLE serum St by quantitative MICROCOMPLEMENT FIXATION WITH CALF THYMUS DNA AND WITH SERUM VA SHOWN BY PRECIPITIN STUDIES TO ContaIN DNA. Serum St had been shown to contain precipitins to DNA.
TABLE II

Serum DNA in other conditions

\begin{tabular}{lcc}
\hline \hline & $\begin{array}{c}\text { No. of sera } \\
\text { tested }\end{array}$ & $\begin{array}{c}\text { Positive } \\
\text { for DNA }\end{array}$ \\
\hline $\begin{array}{l}\text { Leukemia, lymphosarcoma, and } \\
\quad \text { lymphoma }\end{array}$ & 29 & 3 \\
Multiple myeloma & 15 & 0 \\
Acute rheumatic fever & 9 & 0 \\
Rheumatoid arthritis & 17 & 0 \\
$\begin{array}{l}\text { Liver disease } \\
\text { Miscellaneous (myocardial infarction, } \\
\text { renal disease, lung disease, infec- }\end{array}$ & 40 & 6 \\
tion, carcinoma) & 72 & 1 \\
Normal & 30 & 0 \\
\hline
\end{tabular}

were found to be positive. In six patients with liver disease and DNA in the sera, two had cholangiolitic hepatitis, and four had generalized carcinomatosis with metastases to liver. Three patients with lymphosarcoma showed DNA in the serum. The remaining patient with DNA in serum had miliary tuberculosis with high fever. Special studies with sera from other febrile patients did not reveal DNA.

Some evidence was obtained for trace amounts of DNA in a number of additional sera. However, because of the very weak precipitin lines in the immunological assay, these were not included in either the SLE or control survey. Only those were considered positive that gave clear precipitin lines.

\section{Discussion}

The demonstration of a potential antigen, DNA, in the sera of patients with SLE highlights the importance of circulating antibodies as possible pathogenic factors in certain aspects of the disease. In instances where specific DNA antibody was already present in the blood, as was the case in the second patient reported in this study, the possibility is raised that the appearance of antigen resulted in the formation of immune complexes of the DNA-anti DNA type. Attempts to demonstrate such complexes directly in the serum have thus far failed despite considerable investigation of cryoglobulin and euglobulin fractions. However, it seems very possible that if such complexes were formed, they would be rapidly removed from the circulation and would be very difficult to detect in the serum. Some evidence for such complexes has been obtained by Lachmann in studies of the anticomplementary properties of certain of these sera (25) and also by Lee and Rivero (26). 
However, further investigations are required to establish conclusively a pathogenic role of such possible complexes. In particular, it will be important to demonstrate directly the presence of DNA along with its antibody in kidney sections from these patients. The finding from several laboratories of antinuclear antibodies in the eluates from the glomeruli of these patients is of particular interest (27-29).

The possibility that other antigens arising from tissue breakdown gain access to the circulation and interact with specific antibody certainly requires consideration. A number of soluble tissue components other than DNA have been found that react with antibodies in SLE sera $(14,15,30)$. Specifically, the Sm antigen that has recently been studied (15) might be implicated, since the antibody to this component was present in high incidence in SLE sera. Thus far, however, this antigen has not been found in the serum, although it has been detected in the urine of SLE patients. Irrespective of what types of complexes might predominate, it seems quite likely in view of the studies of Dixon, Feldman, and Vazquez (11) and of Ward and Cochrane (12) in experimental animals that one or more may be implicated in the human renal lesions.

Certain investigators have reported the finding of DNA in normal human plasma (31). However, the procedure of Schmidt and Thannhauser (32) was utilized for determining the phosphorus content of nucleic acids, a technique that has been shown to be unreliable for small quantities of nucleic acids because of phosphoproteins in serum $(33,34)$. With the modified diphenylamine reaction employed in the present study, normal sera which were negative by the immunologic technique gave a slight color reaction corresponding to that given by 1 to $3 \mu \mathrm{g}$ DNA per $\mathrm{ml}$ in saline. It is probable that compounds in serum interfering in color reactions for DNA (35-37) were involved, since such concentrations of DNA would have been detected by the precipitin technique, which was sensitive to a concentration of $1 \mu \mathrm{g}$ DNA per $\mathrm{ml}$ added to normal serum. A recent report (38) described the production of antibody to DNA by immunization of rabbits with normal human serum. The significance of this finding remains undetermined. It has not been established whether anti-DNA antibodies devel- oped as a consequence of hyperimmunization, as has been suggested in animals injected with bacteria (39), or were due to the presence of DNA in selected sera utilized for immunization.

Deoxyribonuclease has been detected in human serum by a number of investigators (40-42). However, the studies of Herriott and his colleagues $(16,43)$ have demonstrated that the enzyme occurs in high concentration in the platelets with relatively small amounts in cell-free plasma. In addition, an inhibitor of the enzyme was observed in cellular elements of blood and in serum. In the present study findings closely analogous to those of Herriott and associates were obtained. The stability of DNA with respect to its antigenicity in precipitin assay was established for most sera if studied soon after withdrawal. Evidence for loss of DNA on long storage at $4^{\circ} \mathrm{C}$ was obtained for a few sera, but the majority showed little change. In many instances plasma as well as serum was analyzed with similar results. It appears that the nuclease in human blood poorly inactivates antigenicity as well as the transforming property of bacterial and viral DNA. The recent study of Bendich, Wilczok, and Borenfreund (44) showed that in the mouse an analogous situation might apply. They demonstrated that ascites cell DNA injected into mice does not break down extensively in the blood and that the major bulk of the injected DNA remains in an acid-insoluble form as macromolecules.

An important question that has not been answered in the present study relates to the origin of DNA found in serum. That DNA was of endogenous origin appeared very likely, since it was found not only in SLE but also in a number of diseases associated with tissue destruction, viz., hepatitis, metastatic carcinoma, and miliary tuberculosis. The association with skin rash in certain SLE patients raises the possibility that tissue breakdown at this site may have given rise to circulating DNA. Some evidence for this possibility stems from recent studies of skin biopsies in which lumpy deposits of deoxyribonucleasesensitive material coated with antibody were observed (13). Direct evidence was obtained here for the local formation of antigen-antibody complexes. Free DNA also has been observed in joint fluid from inflamed joints by the gel diffusion method, and this could represent a possible 
source. However, in the absence of complete data characterizing the physical and chemical properties of serum DNA, the possibility has not been excluded that it could be of exogenous origin.

\section{Summary}

Gel diffusion studies have demonstrated the presence of DNA antibodies of varying specificities in the serum of patients with systemic lupus erythematosus (SLE). These antibodies could be employed in a sensitive and specific method for detecting DNA in serum, and native DNA could be distinguished from denatured (single strand) DNA. With this technique, native type DNA was found to be present in the serum of a few patients with systemic lupus erythematosus and other diseases. This finding was confirmed by chemical assay for DNA.

Serial studies with the sera of certain patients with SLE indicated that DNA was present at one time, whereas antibodies to DNA were present at another. Such sera interacted with each other by precipitin and complement fixation reactions. The possibility is raised that DNA and anti-DNA antibodies may have occurred simultaneously, giving rise to antigen-antibody complexes of potential significance in the renal lesions.

\section{Acknowledgments}

The authors are very much indebted to Drs. Charles Christian, Jane Morse, Naomi Rothfield, John Sandson, Ralph Schrohenloher, and Maxim Seligmann for certain of the SLE sera utilized in this study. The technical assistance of Miss A. Horasanci is also gratefully acknowledged.

\section{References}

1. Tan, E. M., P. H. Schur, and H. G. Kunkel. DNA in the serum of patients with systemic lupus erythematosus (SLE) (abstract). J. clin. Invest. $1965,44,1104$.

2. Seligmann, M. Mise en évidence dans le sérum de malades atteints de lupus érythémateux disséminé d'une substance déterminant une réaction de précipitation avec l'acide désoxyribonucléique. C. R. Acad. Sci. (Paris) 1957, 245, 243.

3. Ceppellini, R., E. Polli, and F. Celada. A DNAreacting factor in serum of a patient with lupus erythematosus diffusus. Proc. Soc. exp. Biol. (N .Y.) 1957, 96, 572.

4. Robbins, W. C., H. R. Holman, H. Deicher, and H. G. Kunkel. Complement fixation with cell nu- clei and DNA in lupus erythematosus. Proc. Soc. exp. Biol. (N. Y.) 1957, 96, 575.

5. Miescher, P., and R. Strässle. New serological methods for the detection of the L.E. factor. Vox Sang. (Basel) 1957, 2, 283.

6. Kunkel, H. G., and E. M. Tan. Autoantibodies and disease in Advances in Immunology, F. J. Dixon and J. H. Humphrey, Eds. New York, Academic Press, 1964, vol. 4, p. 351.

7. Seligmann, M., and F. Milgrom. Mise en évidence par la fixation du complément de la réaction entre acide désoxyribonucléique et sérum de malades atteints de lupus érythémateux disséminé. C. $R$. Acad. Sci. (Paris) 1957, 245, 1472.

8. Casals, S. P., G. J. Friou, and L. L. Myers. Significance of antibody to DNA in systemic lupus erythematosus. Arth. and Rheum. 1964, 7, 379.

9. Germuth, F. G., Jr., and G. E. McKinnon. Studies on the biological properties of antigen-antibody complexes. I. Anaphylactic shock induced by soluble antigen-antibody complexes in unsensitized normal guinea pigs. Bull. Johns Hopk. Hosp. 1957, 101, 13.

10. Benacerraf, B., J. C. Potter, R. T. McCluskey, and F. Miller. The pathologic effects of intravenously administered soluble antigen-antibody complexes. II. Acute glomerulonephritis in rats. J. exp. Med. 1960, 111, 195.

11. Dixon, F. J., J. D. Feldman, and J. J. Vazquez. Experimental glomerulonephritis. The pathogenesis of a laboratory model resembling the spectrum of human glomerulonephritis. J. exp. Med. 1961, 113, 899.

12. Ward, P. A., and C. G. Cochrane. Bound complement and immunologic injury of blood vessels. J. exp. Med. 1965, 121, 215.

13. Tan, E. M., and H. G. Kunkel. An immunofluorescent study of the skin lesions in systemic lupus erythematosus. Arthr. and Rheum. 1966, 9, 37.

14. Anderson, J. R., K. G. Gray, J. S. Beck, W. W. Buchanan, and A. J. McElhinney. Precipitating auto-antibodies in the connective tissue diseases. Ann. rheum. Dis. 1962, 21, 360.

15. Tan, E. M., and H. G. Kunkel. Characteristics of a soluble nuclear antigen precipitating with sera of patients with systemic lupus erythematosus. J. Immunol. 1966, 96, 464.

16. Gupta, S., and R. M. Herriott. Nucleases and their inhibitors in the cellular components of human blood. Arch. Biochem. 1963, 101, 88.

17. Wasserman, E., and L. Levine. Quantitative microcomplement fixation and its use in the study of antigenic structure by specific antigen-antibody inhibition. J. Immunol. 1961, 87, 290.

18. Giles, K. W., and A. Myers. An improved diphenylamine method for the estimation of deoxyribonucleic acid. Nature (Lond.) 1965, 206, 93.

19. Mirsky, A. E. Personal communication.

20. Stollar, D., L. Levine, H. I. Lehrer, and H. van Vunakis. The antigenic determinants of denatured 
DNA reactive with lupus erythematosus serum. Proc. nat. Acad. Sci. (Wash.) 1962, 48, 874.

21. Butler, V. P., Jr., S. M. Beiser, B. F. Erlanger, S. W. Tanenbaum, S. Cohen, and A. Bendich. Purine-specific antibodies which react with deoxyribonucleic acid (DNA). Proc. nat. Acad. Sci. (Wash.) 1962, 48, 1597.

22. Tanenbaum, S. W., and S. M. Beiser. Pyrimidinespecific antibodies which react with deoxyribonucleic acid (DNA). Proc. nat. Acad. Sci. (Wash.) 1963, 49, 662.

23. Sela, M., H. Ungar-Waron, and Y. Shechter. Uridine-specific antibodies obtained with synthetic antigens. Proc. nat. Acad. Sci. (Wash.) 1964, 52, 285.

24. Plescia, O. J., W. Braun, and N. C. Palczuk. Production of antibodies to denatured deoxyribonucleic acid (DNA). Proc. nat. Acad. Sci. (Wash.) 1964, 52, 279.

25. Lachmann, P. J. Unpublished observations.

26. Lee, S. L., and I. Rivero. Cryoglobulins in systemic lupus erythematosus (SLE) as circulating immune complexes (abstract). Arth. and Rheum. 1964, 7, 321.

27. Freedman, P., and A. S. Markowitz. Gamma globulin and complement in the diseased kidney. J. clin. Invest. 1962, 41, 328.

28. Graf, M., and D. Koffler. Elution of glomerularbound antibody in systemic lupus erythematosus. Fed. Proc. 1966, 25, 659.

29. Krishman, C., and M. H. Kaplan. Antinuclear activity in acid eluates of glomeruli from lupus nephritis kidneys. Fed. Proc. 1966, 25, 309.

30. Holman, H. R., H. R. G. Deicher, and H. G. Kunkel. The L.E. cell and the L.E. serum factors. Bull. N. Y. Acad. Med. 1959, 35, 409.

31. Mandel, P., and P. Métais. Les acides nucléiques du plasma sanguin chez l'homme. C. R. Soc. Biol. (Paris) 1948, 142, 241.

32. Schmidt, G., and S. J. Thannhauser. A method for the determination of deoxyribonucleic acid, ribo- nucleic acid, and phosphoproteins in animal tissues. J. biol. Chem. 1945, 161, 83.

33. Pirie, N. W. Some chemical methods for the detection and rough estimation of agar in biological materials. Brit. J. exp. Path. 1936, 17, 269.

34. Leslie, I. The nucleic acid content of tissues and cells in The Nucleic Acids, E. Chargaff and J. N. Davidson, Eds. New York, Academic Press, 1955, vol. 2 , p. 1.

35. Ayala, W., L. V. Moore, and E. L. Hess. The purple color reaction given by diphenylamine reagent. I. With normal and rheumatic fever sera. J. clin. Invest. 1951, 30, 781.

36. Dische, $Z$. Color reactions of nucleic acid components in The Nucleic Acids, E. Chargaff and J. N. Davidson, Eds. New York, Academic Press, 1955, vol. 1, p. 285.

37. Lee, J. B. Compounds interfering in the diphenylamine test for deoxyribonucleic acid. Nature (Lond.) 1963, 200, 264.

38. Barnett, E. V., and J. H. Vaughan. Antinuclear antibodies in rabbit antisera. J. exp. Med. 1966, 123, 733.

39. Christian, C. L., A. R. DeSimone, and J. L. Abruzzo. Anti-DNA antibodies in hyperimmunized rabbits. J. exp. Med. 1965, 121, 309.

40. McCarty, M. The inhibition of streptococcal desoxyribonuclease by rabbit and human antisera. J. exp. Med. 1949, 90, 543.

41. Wroblewski, F., and O. Bodansky. Presence of deoxyribonuclease activity in human serum. Proc. Soc. exp. Biol. (N. Y.) 1950, 74, 443.

42. Kurnick, N. B. Deoxyribonuclease activity of sera of man and some other species. Arch. Biochem. 1953, 43, 97.

43. Herriott, R. M., J. H. Connolly, and S. Gupta. Blood nucleases and infectious viral nucleic acids. Nature (Lond.) 1961, 189, 817.

44. Bendich, A., T. Wilczok, and E. Borenfreund. Circulating DNA as a possible factor in oncogenesis. Science 1965, 148, 374. 